\title{
Gaveøkonomi - en vej til velfærd
}

\section{VELF/ERD • LEDELSE • GAVEOKONOMI • PENGEOKONOMI SOCIO-ØKONOMI - SYSTEMTEORI}




\section{Gaveøkonomi - en vej til velfærd}

\section{VELFARD • LEDELSE • GAVEOKONOMI • PENGEØKONOMI SOCIO-OKONOMI - SYSTEMTEORI}

Resumé: Artiklen bidrager med et teoretisk-illustrativt bud på, hvordan en lovende gaveøkonomi kan bidrage med en vej til velfærd og ikke mindst en vej ud af det økonomiske efterslæb, som COVID-19 har skabt. Gaveøkonomi er en økonomisk udveksling, der skaber velfærdsværdi gennem relationer, dvs. hvor hver part får adgang til det, som andre giver (gaver), ved selv at give (gengave). Som sådan udgør gaveøkonomien et andet medie for udveksling end penge, som skaber velfærdsværdi gennem adskillelse. Budskabet er, at gaveøkonomien principielt er pengeøkonomien overlegen målt på velfærdsværdi. Denne tese finder evidens i fire illustrative cases fra den danske offentlige sektor og understøttes desuden af det politologiske-socioøkonomiske forskningsfelt. 


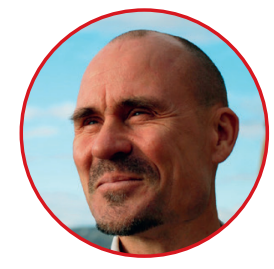

Niels Thygesen

Niels Thygesen har en PhD i offentlige ledelse fra Copenhagen Business School (CBS) og arbejder i dag som lektor på institut for Ledelse, Politik \& Filosofi, CBS.

Niels har i mange år forsket i velfærd og ledelse og beskæftiget sig med tematikker som tillid, ledelsesteknologier, tid, gaveøkonomi og velfærdsværdi. Han har publiceret en lang række artikler om emnerne i såvel danske som internationale tidsskrifter. Senest bogen 'Gaveøkonomi - ny vej til bedre velfærd', Gyldendal Public. Niels er også en flittigt benyttet foredragsholder. 
"Corona har bremset indsatsen på en lang række områder i den kommunale velfærd. Hvis det skal indhentes på den anden side af corona, skal Christiansborg hoste op med flere penge, når KL og finansministeren mødes til forhandlinger om kommunernes økonomi." Sådan lød budskabet $\mathrm{i}$ Nyhedsmagasinet Danske Kommuner d. 18. marts 2021. Citatet bringes for at vise hvordan det pengeøkonomiske rationale dominerer, når det gælder velfærd i almindelighed og coronakrisen $\mathrm{i}$ særdeleshed.

Artiklens første hovedpointe består i at iagttage pengeøkonomiens opfattelse af, hvad der tæller som velfærdsværdi. Det giver os en unik mulighed for at træde ud af den pengeøkonomiske iagttagelsesmaskine og sætte spørgsmålstegn ved, om disse iagttagelser er de eneste økonomiske iagttagelser, der findes, samt hvorvidt og hvordan andre økonomier stiller andre iagttagelser af velfærd til rådighed.

Artiklens anden hovedpointe er, at der findes et økonomisk alternativ til pengeøkonomien, hvorved velfærden i samfundet kan iagttages og dermed genopbygges. Alternativet hedder gaveøkonomi. Denne økonomi er ikke blot interessant, fordi det er en økonomi, hvis udvekslinger er baseret på relationer frem for på adskillelse, men fordi det viser sig, at dens velfærdsværdi teoretisk-principielt overgår pengeøkonomiens.

\section{De to hovedpointer danner tilsammen artiklens budskab: At der findes et alternativ til pengeøkonomi, som er gaveøkonomi, og at den principielt er pengeøkonomien overlegen målt på velfærdsværdi. Denne tese underbyg- ges af fire illustrative og eksemplariske cases fra den danske offentlige sektor, og desuden understøttes den af et politologisk-socioøkonomisk forskningsfelt.}

Men hvordan er det overhovedet muligt at forestille sig et økonomisk potentiale ved siden af pengeøkonomien? Svaret (læs: tesen) på spørgsmålet bliver opbygget gennem artiklens fire dele: Artiklen indledes med et eksempel på gaveøkonomiens målelige velfærdsværdi. Dernæst beskrives artiklens analysestrategi (del 1), dvs. med hvilke begreber sammenligningen mellem de to økonomier foretages. Dernæst foretages en teoretisk-principiel sammenligning mellem pengeøkonomiens og gaveøkonomiens velfærdspotentiale (del 2). Analysen afløses af tre eksemplariske cases foruden det indledende eksempel, der på forskellig vis også illustrerer gaveøkonomiens målelige velfærdsværdi, efterfulgt af en overbliksmodel, der fordeler gaveøkonomierne hen over akserne digital-fysisk og større-mindre (del 3). I den afsluttende konklusion sammenfattes bidraget i en diskussion af, de politiske, ledelses- og forskningsmæssige udfordringer, der er forbundet med at fremme vejen til velfærdsværdi gennem gaveøkonomi. Men først et eksempel på gaveøkonomi. I Randers Kommune har de fundet et alternativ til pengeøkonomien, som er gaveøkonomien, og kommunen har vist, at dens velfærdspotentiale er værd at bygge på. Som artiklen uddyber senere, så bygger gaveøkonomiens værdi på relationer, fordi hver part får adgang til det, som den eller de andre giver (gaver), ved selv at give (gengave).

"Lån et lokale, og gør de ældre glade." Sådan lyder det fra seks ældrecentre i kommunen, der giver foreninger mulighed for at booke de tomme møde- og forsamlingslokaler i weekenden og i aftentimerne ${ }^{1}$. Det er gratis for foreningerne at låne lokalerne (gave). Men det er ofte en betingelse, at de aktiviteter, der foregår, skal "bidrage til centrets liv" - for eksempel ved at inddrage beboerne i aktiviteterne (gengave). På den måde får hver part adgang til det, som den eller de andre giver (gave) ved selv at give (gengave), hvilket har større værdi for alle, end hvis de lod være. Her er nogle af de aktiviteter, der er skabt gennem gaveøkonomien, og som har værdi for alle parter: 
1) Lungeforeningen Danmark og aftenskolerne har nu to faste lungekor for KOL-patienter og kræftsyge. 2) Babysalmesang er nu en fast aktivitet på Åbakken i Øster Tørslev, på Borupvænget og i Kollektivhuset i Randers C til glæde for både ældre og yngre. 3) Yoga- og pilateshold har fået deres faste gang på en række ældrecentre, hvor de stille aftentimer fyldes med blød musik, mens roen falder over både deltagere og beboere. 4) Randers Egnsteater holdt forpremiere på sin forestilling VÆK på Tirsdalens ældrecenter. 5) Hver søndag får Tirsdalen besøg af den lokale bogklub.

Bogklubben har længe ledt efter et handicapvenligt lokale, da to af deltagerne sidder i kørestol. Nu har de fundet sig til rette i et mødelokale med god adgang og handicaptoilet, så bøger kan blive læst (op) og diskuteret af klub sammen med ældre.

At de værdifællesskaber, der er skabt på ældreområdet i Randers Kommune, er et eksempel på gaveøkonomiens udvekslingsprincip og dens værdi, kan der ikke være tvivl om. Samtidig er det værd at notere sig, at hvis den samme værdi skulle skabes pengeøkonomisk, ville regnestykket ikke gå op. ÆEldrecentrenes driftsbudgetter ville ikke kunne rumme den betragtelige mængde ekstraansættelser, der skulle til for at matche samme mængde nærvær og aktiviteter. Og foreningerne ville ikke ud af egen lomme have råd til at leje hvert sit lokale til egne aktiviteter. Med andre ord: Det kan betale sig at iagttage og arrangere velfærd som gaveøkonomi, fremfor udelukkende pengeøkonomisk

\section{Del 1: Analysestrategi}

I udviklingen af artiklens tese anvendes en systemteoretisk inspireret analysestrategisk tilgang, der betoner iagttagelser af iagttagelser (Andersen, 2003). lagttagelser skal her ikke forstås som øjet, der ser, men som de iagttagelser, der dukker op i kommunikationen (Luhmann, 1995).

Mere præcist er der tale om iagttagelsen af de iagttagelser af velfærdsværdi, som de to økonomier stiller til rådighed, og som gør det muligt at kommunikere om den. I Randers blev velfærd iagttaget gennem den iagttagelsesledende forskel, som gaveøkonomien stiller til rådighed (gave/gengave), og efterfølgende blev det muligt at organisere velfærden blandt ældrecentrene anderledes end hidtil.

Med udgangspunkt i systemteorien er der udviklet et rigt mål af analysestrategiske tilgange (fx Knudsen, 2014; Thygesen, 2007; Andersen, 2003). Den metode, der anvendes her, er funktionel metode (Knudsen, 2014). Knudsen understreger, at funktionel metode gør det muligt at sammenligne det undersøgte fænomen ( $\mathrm{fx}$ pengeøkonomi) med funktionelle ækvivalenter ( $\mathrm{fx}$ gaveøkonomi) - en sammenligning, der i nærværende artikel giver distance til pengemediet, fordi det ses i lyset af dets alternativ, gaven.

Denne analysestrategi beder derfor her om at gøre rede for, hvordan økonomiernes iagttagelser iagttages. I dette tilfælde sker det gennem fire udvalgte begreber: form og medie (Andersen, 2019), program (Luhmann, 2000, kap 4; Thyssen, 2000) samt velfærdsværdi opgjort i form af hard value og social, som redegjort for af Thygesen og Löfvall (2020) og Thygesen $(2019,2020)$. 


\section{Form og medie}

Penge er et medie, fordi det medierer udvekslingen mellem to eller flere parter. Det samme gælder gavemediet, der også medierer udvekslinger, omend på en anden måde.

Både penge og gave kan man kalde supermedier i den forstand, at de ækvivalerer Luhmanns begreb om symbolsk generaliserede medier (Luhmann, 2016, kap 2). I dette tilfælde fordi der i princippet, men også kun i princippet (!), kan sættes penge og pris på alt og alle, selvom det ikke er alt og alle, der bliver penge- og prissat. Det samme gælder gaven. Alt og alle kan i princippet, men kun i princippet (!), henregnes som gave. Man bidrager med det, man har, eller det, man kan, selvom ikke alt, hvad man har og kan, gøres til bidrag.

Hvert medie stiller en form til rådighed, som betyder, at den måde, vi iagttager udvekslingen mellem parter på, ikke er tilfældig.

Penge forudsætter evnen til at betale og udelukker derfor ikke-betalinger. Pengemediet stiller altså formen betale/ikke betale til rådighed (Luhmann, 1982). På et trin lavere niveau formgiver penge den økonomiske udveksling som en transaktion, hvor formen, der stilles til rådighed, er varer/penge eller, som det er tilfældet i den offentlige sektor, ydelse/penge (Boldyrev, 2013).

Gaven, derimod, er et andet medie, der stiller en anden form til rådighed. Gavemediet tilbyder formen gave/gengave. Forholdet mellem gave og gengave består i forpligtelsen til at give (når du har modtaget), forpligtelsen til at modtage (når du har givet), og forpligtelsen til gensidighed (reciprocitet) (Mauss, 2002/1925; Bourdieu, 1996, 1979). Og det er en økonomisk udveksling, hvis velfærdsværdi - som allerede anført - baserer sig på adgang: Hvor hver part får adgang til det, som andre giver (gaver) ved selv at give (gengave) (Thygesen \& Löfvall, 2020; Thygesen 2019, 2020) Som de fx gør det i Randers.

\section{Program}

Form-medie-distinktionen bistås af program-begrebet. Det er der to grunde til. For det første fordi organisationsprogrammer giver adgang til iagttagelsen af organisationers formelle organiseringer af egne (økonomiske) iagttagelser. For det andet fordi de giver adgang til iagttagelsen af den programmerede og dermed forventede og ofte efterfølgende formelt registrerede velfærdsværdi, der følger med disse organiseringer.

Men hvad er programmer så?

Programmer er organiserede præmisser for beslutninger, der i sig selv er besluttede. Fx er det et beslutningspræmis i mange kommuner, at tildeling af ressourcer foregår i form af normeringer, og at opgørelsen af velfærd vurderes i form af ydelsernes enhedsomkostninger. Til forskel herfra udgør et gaveprogram $\mathrm{fx}$ de forpligtelser ( $\mathrm{fx}$ retningslinjer), eller platforme ( $\mathrm{fx}$ digitale) der ligger til grund for organiseringen af velfærdsværdi, som vi så blandt de seks ældrecentre i Randers Kommune.

Det er altså økonomiske programmer, hvis iagttagelser iagttages. Og det er i særdelshed med et blik for programmeret velfærdsværdi. Her opgjort som hard value og social value. 


\section{Hard value og social value}

Hvad angår velfærdsværdi, skelnes der mellem to typer af værdi. Som sådan er hard value og social value analysestrategiske begreber, men de er også ment som begreber, hvormed vi i det hele taget kan få (be-) greb om velfærdsværdi i samfundet.

Kort sagt er hard value den 'objektive' og udregnede værdi, og social value er den 'oplevede' og sociale værdi. Distinktionen mellem hard value og social value svarer fx til, at den nuværende regering ønsker en 70 \% reduktion af CO2-udslippet inden 2030 (hard value), men samtidig understreger, at det ikke må gå ud over den sociale bæredygtighed og oplevelsen af at være en del af fællesskabet og fællesskaber (social value).

Distinktionen anvendes også inden for flere økonomiske discipliner. Inden for den klassiske økonomi er det ikke ualmindeligt at fokusere på hard value, fx makroøkonomisk (BNP) eller mikroøkonomisk (bundlinjen), men i samme takt ofte at ignorere eller endda bevidst fraregne sociale faktorer og social value for at få de økonomiske ligevægtsmodeller til at gå op (Acemoglu, Laibson \& List, 2019). Inden for socio-økonomien forholder det sig omvendt, da dette forskningsfelt gør en dyd ud af at medtage det sociale i det økonomiske (fx Graeber, 2013). Især ser vi distinktionen i spil inden for de dele af feltet, hvor der arbejdes med at undersøge samfundsværdien af sociale økonomier eller flere økonomier ( Fukuyama, 1995; Putnam, 1995, 2000, 2004). Samme tilgang ser vi inden for flere organisationsanalyser (Gabbay \& Leenders (red.), 2001; Hasle et al., 2010; Olesen et al., 2008; Moltke \& Graff, 2014).

Når det så er sagt, så skal det ikke komme bag på nogen, at der er deciderede mørke sider ved begge økonomier beskrevet af Mauss (2002/1925) og videreudviklet af Bourdieu (1996, 1979). Pengeøkonomien, ved vi, bruges også til bestikkelse og magtmisbrug - selv i en offentlig kontekst. Og gaveøkonomiske mekanismer er udbredte i kriminelle miljøer og uformelle økonomier, når den ene tjeneste er den anden værd - hvilket vi desværre heller ikke er ubekendt med i en offentlig kontekst ${ }^{2}$. Disse relevante kritikker uddybes ikke her, da det er økonomiernes velfærdspotentiale, der sammenlignes, og melder sig derfor som en blind plet! Derfor er det også værd at understrege, at det udelukkende er de formelle programmer i det offentlige, der er politisk vedtaget og juridisk autoriseret, der gøres til genstand for iagttagelse, og ikke de mere eller mindre formelle kodeks, der fx er produceret blandt landets rockerborge (kriminelle miljøer), og dem, der er mere eller mindre udbredte som kulturelle aflejringer i uformelle økonomier (sort arbejde).

Det er også værd at understrege, at adskillelsen mellem de to økonomier er en analytisk adskillelse, der har til formål at understrege tilstedeværelsen af begge og især understrege værdipotentialet i gaveøkonomien. I praksis hænger de ofte uløseligt sammen. Gaver kan købes for penge, og penge kan gives som gaver. Og I Randers har koordinationen af gavegivningen givetvis medført nogle udgifter, ligesom gavegivningen har bidraget til reduceringen af samme.

\section{Empiri}

Eftersom det ikke er første gang, at der foretages en analyse af to økonomier, refererer artiklen til disse analyser frem for til primærempiri. Analyserne udgør den del af det socioøkonomiske forskningsfelt, der sætter pengeøkonomien i spil over for de udvekslingsprincipper, fx ressourceudvekslinger og ressourcemobiliseringer, der er (tæt på) gaveøkonomiske (Graeber, 2013; Eisenstein, 2011; Fukuyama; 1995; Putnam, 1995, 2000, 2004). De udgør også den del af den offentlige institutionelle historie, der beskæftiger sig med overgangen fra velfærd som et omsorgs- 
og juridisk begreb (universalismen) til velfærd som et økonomisk- og konkurrencebegreb, defineret ved managementstaten og konkurrencestaten (Ejersbo \& Greve, 2014; Pedersen, 2011; Pedersen, 2004). I de fire illustrative cases udgøres case-materialet af policy papers, formelle beskrivelser og selvfremstillinger samt de kilder, som de henviser til.

\section{Del 2: Pengeakonomien og gavedkonomien}

Efter denne indledende analysestrategi bevæger artiklen sig over i den teoretisk-illustrative sammenligning af pengeøkonomiens og gaveøkonomiens velfærdspotentiale. En smagsprøve på gaveøkonomisk velfærdsværdi blev allerede givet i indledningen, og tesen, der udvikles, er, at gaveøkonomien principielt er pengeøkonomien overlegen målt på værdiskabelse (hard value og social value).

\section{Penge og gaver som medie og form}

Penge og gaver er begge et medie for økonomiske udvekslinger, men hvert medie giver forskellig form til udvekslingerne og dermed skabelsen af værdi.

Pengeøkonomiens form, når det gælder økonomiske transaktioner, er som nævnt vare/penge eller ydelse/penge (Boldyrev, 2013). Det kommer ikke bag på nogen, at New Public Management (NPM) har mimet denne form og ikke mindst i sin økonomiske retorik (Pedersen, 2011; Petersen, 2004). Offentlige institutioner bliver benævnt 'virksomheder', service omtales som 'ydelser' og opgjort i enhedsomkostninger, mens borgere omtales som 'kunder'.

Denne mikro-økonomiske drejning under NPM blev sluset ind i en makroøkonomisk vending, der tegner den nuværende konkurrencestat, og hvis reform-, og lovgrundlag var dybt inspireret af velfærdskommissionens arbejde (2003-2005) ${ }^{3}$. Denne tilbød blandt mange andre iagttagelser iagttagelsen af borgeren som opdelt i gennemsnitlig samfundsudgift (0-23 år og pensionsalderen) og gennemsnitlig samfundsindtægt (mellem 23 og pensionsalder). Derefter kunne man arbejde med at nedbringe udgiften og øge indtægten via forskellige reformer som fx fremdriftsreformen, efterlønsreformen, dagpengereformen, aktiveringsreformen osv.

Det er derfor ikke så mærkeligt, at størstedelen af den offentlige sektor følger en pengeøkonomisk organisering af velfærden. Den baserer sig igen på adskillelse, og det på trods af, at flere forskellige koordinerings- og agilitetsprincipper vinder frem. Størstedelen af den offentlige service leveres af medarbejdere, opgaver og funktioner, som isoleres fra hinanden, eller bliver målt og evalueret, som om de var det. Og endelig tilfalder ydelserne gennem dette leverancesystem målgrupper og enkeltpersoner, som heller ikke forudsættes at have meget med hinanden at gøre (Thygesen \& Löfvall, 2020: kap. 4,5,6,7).

Sagt meget kort, så blev den mikroøkonomiske drejning sluset med over i den makroøkonomiske, og tilsammen udgør de to 'drejninger' et overgribende, pengeøkonomisk rationale (Pedersen, 2011). Af samme grund kan det ikke undre at Nyhedsmagasinet Danske Kommuner i sit opråb opfordrer til, at Christiansborg skal hoste op med flere penge, når coronapandemien har bremset indsatsen på en lang række områder i den kommunale velfærd. 
Til forskel fra pengeøkonomien tilbyder gaveøkonomien en anden form for økonomisk udveksling, der består i gave/gengave.

\section{Når parterne konverterer til gaveøkonomi, så består den af en anden form for økonomisk udveksling end den pengeøkonomiske og derfor også en anden værdi. Som nævnt: at give og selv få adgang til det, som andre giver. Som det var tilfældet i Randers Kommune.}

I pengeøkonomien er der altså tale om, at man bliver 'rig ved at modtage', dvs. modtage den isolerede ydelse, og det på baggrund af den skat og de afgifter, man som borger har betalt. Med gaveøkonomien forholder det sig omvendt. Alle parter bliver 'rig ved at gi', fordi gaven giver adgang til det, den anden eller de andre også giver, og det gælder for alle bidragende parter (Nørretranders, 2003).

Det er ikke nogen hemmelighed, at også gaven har sin historik, ligesom pengeøkonomien. Den skal ses i lyset af en historisk underskov af lokale demokratier, foreningsaktiviteter og bevægelser og dermed på en traditionsbestemt og velkendt økonomi i dansk kontekst. Den lå fx langt hen ad vejen til grund for opbygningen af de danske andelsbevægelser. Et økonomisk mirakel, hvor gårdejeren $\mathrm{fx}$ bidrog med en forholdsvis lille andel - $\mathrm{fx}$ en såmaskine, serviceringen heraf eller et beløb - fordi andelen gav adgang til benyttelse af en komplet station med maskiner, der dækkede den årlige produktion. Men det er heller ikke nogen hemmelighed, at disse gaveøkonomier blev udfaset under en heftig og tiltagende pengeøkonomisk centralisering; først med korporatismen og senere under managementstatens NPM-principper og konkurrencestaten (Pedersen, 2011; Pedersen, 2004).

Hverken medie eller form giver indsigt i økonomiernes værdiprincip. Blot at den form, som hvert medie tilbyder, vender værdiprincippet om, fra at modtage sin ydelse og kræve sin ret, til at give og få adgang til, hvad andre giver. Så spørgsmålet er, hvad gaveøkonomiens programmerede værdi er, sammenlignet med pengeøkonomiens? Hermed bliver det teoretisk-principielt muligt at præcisere, hvad gaveøkonomiens velfærdspotentiale består af, velvidende, at potentialet i praksis bliver højst forskelligt indløst og udfoldet.

\section{Hard value}

Hard value udgør den målbare værdi. Anskuet som hard value indebærer pengeøkonomiens transaktioner to typer af adskillelse (Eisenstein, 2011). Den første adskillelse består i, at den, der køber varen, som regel ikke har noget at gøre med den, der sælger varen. Vi går ind i transaktionen som adskilte, og vi går ud af transaktionen som adskilte. Denne adskillelse har også fået navnet nulsumsspil, fordi varen i princippet kun bytter plads med pengene (Bierman \& Fernandez, 1998; Mas-Colell, A. et al., 1995; Gibbons, 1992). Der er med andre ord ikke skabt merværdi. Nulsum svarer i realiteten til de situationer, hvor velfærd via offentligt finansierede reformer bliver udmålt i indsatser, nedbrudt i ydelser og tildelt hver bruger, der har betalt for denne rettighed over skatter og afgifter. I Randers vil det svare til, at hver enkelt på plejehjemmet modtager en afmålt ydelse (fysisk aktivering i form af yoga og pilates) af en visiteret fysioterapeut, og som måske er finansieret over plejehjemmets eget driftsbudget.

Den anden adskillelse består i, at den, der køber varen, adskilles fra de andre, der køber varen. Ingen behøver at have noget med hinanden at gøre. Dette nulsumsspil svarer i det offentlige til, at de, der leverer ydelsen, ikke behøver at have noget med hinanden at gøre, ligesom $\mathrm{fx}$ de ældre, der modtager ydelsen, heller ikke behøver det. 
Til forskel fra pengeøkonomiens adskillelser bygger og opbygger gaveøkonomien på relationer. Relationer opstår, når den ene part giver og selv får adgang til det, som andre giver. Når der er tale om hard value, udgør gaveøkonomien, til forskel fra pengeøkonomien, også et plussumsspil, fordi der skabes merværdi (Jie, 2011; Kumar, 2011).

Gaveøkonomiens plussum viste sig i praksis på ældreområdet i Randers. Det var den målbare service, som centrene nu kan levere uden at belaste driftsbudgettet. Set fra foreningernes side, så svarer den til de gode, handicapvenlige lokaler, som gaveøkonomien giver adgang til, og som ellers ville have været omkostningstunge for hver forening at leje. Med en lommeregner i hånden kan man forholdsvis nemt opstille et regnestykke for begge parter, der viser gaveøkonomiens besparelser, samt hvilken velfærdsværdi den har skabt, sammenlignet med pengeøkonomiens.

I princippet er plussum baseret på, at den ene part ejer noget, der er til nytte for den anden og vice versa. Plussum udvikler sig endda til multiplicering, når en tredjepart, en fjerdepart ... deltager i gaveøkonomien. For nytteværdien multipliceres, for hver gang en ny part melder sig, og derfor kan man tale om gaveøkonomiens multipliceringseffekt.

Allerede her er vi inde på en kolossal omvæltning af klassisk økonomi, fordi citronen ikke presses. Citroner multipliceres. Det er denne principielle gaveøkonomiske værdimekanisme, som Randers benytter sig af. Og det er den mekanisme, som flere offentlige organisationer eksperimenterer med, når de engagerer sig i forskellige typer af ressourceudvekslinger såsom deleøkonomi, cirkulær økonomi og bytteøkonomi (Thygesen \& Löfvall, 2020, kap 9) samt flere former for samskabelser (Sørensen \& Torfing, 2018).

Flere af de topforskere, der beskæftiger sig med socio-økonomier, anerk-
ender værdien i de fællesskaber, hvor der mobiliseres og udveksles res-
sourcer. Langt de fleste af disse fællesskaber udgør gaveøkonomier, fordi
man giver og derved selv får adgang til de goder, som andre bidrager med.
Og der er allerede sat tal på værdien (Fukuyama, 1995; Putnam, 1995,
2000, 2004). Fukuyama pegede fx på, at kun ca. 60 pct. af et lands økono-
miske vækst kan forklares pengeøkonomisk. De resterende 40 pct. af-
hænger af styrken af landets sociale relationer. Når han målte sig frem til
samfundsværdien af relationer, så er det, fordi han målte på tilfælde som i
Randers på et aggregeret niveau.

Men der er endnu en forskel mellem pengeøkonomien og gaveøkonomien, hvad angår hard value. Den består i, at det kun er penge (skatter og afgifter), der indgår i den økonomiske transaktion, men at så meget andet gælder som gave. En gave kan være noget materielt. Den kan også være immateriel, fx særlige kompetencer og viden, praktiske eller administrative færdigheder, kendskab til et netværk osv.

Det gør gaveøkonomien langt mere inklusiv end pengeøkonomien, fordi der er plads til flere former for bidrag og derfor også til at løfte kæmpeopgaver som fx den manglende omsorg i vores ældrepleje. Det giver ældrecentrene i Randers en betragtelig fordel, da deres pleje nu ikke længere kun afhænger af driftsbudgettet, men også af det, man kan kalde for gavebudgettet.

Der er altså ikke tvivl om, at relationer er altså noget værd. Pengeøkonomiens nulsum kommer ikke i nærheden af gaveøkonomiens plussum. Det er det potentiale, der bliver aktiveret i Randers. Og det er det potentiale, som Fukuyama satte tal på. 


\section{Social value}

Nu kunne man stoppe her, for den værdi, der lader sig beregne på en lommeregner, er den værdi, som vi ofte stiller os tilfredse med. Men gaveøkonomien producerer endnu en værdi oven i hard value, og det er social value (Putnam,1995, 2000, 2004).

I et pengeøkonomisk univers, der består af økonomiske transaktioner, har man i princippet ikke noget med hinanden at gøre. Til forskel herfra er social value integreret i gaveøkonomien. Det skyldes forpligtelse. I en gaveøkonomisk terminologi forpligtelsen til at give (når du har modtaget), forpligtelsen til at modtage (når du har givet), og forpligtelsen til vedvarende at gengælde (reciprocitet). I gaveøkonomien er relationen mellem mennesker altså en relation båret af den forpligtelse, det indebærer at indgå i værdiskabende fællesskaber.

I modsætning til hard value er social value ikke blot en oplevelsesværdi, men også for mange livskvalitet, da de fleste af os ikke kan leve uden oplevelsen af at skabe noget sammen med andre (Kielburger et al., 2018; Eisenstein, 2011). Vender vi tilbage til Randers, begynder parterne i gaveøkonomien utvivlsomt at lære hinanden at kende. I langt de fleste tilfælde opstår der et fællesskab ud af disse gavestrømme. Derfor bruger man også udtrykket 'at sætte pris på hinanden', fordi den anden eller de andre er noget værd for én selv. Derfor forpligter man sig.

\section{Social value i form af forpligtende værdifællesskaber kan udvikle sig i mange retninger og antage mange former. Men som oftest bliver man glad i låget og lys i sindet, når man er en del af et fællesskab (Hermansen \& Nørretranders, 2013). Det bliver man som ældrecenter, når man sammen med foreningerne gør en forskel for andre og øger glæden. Det bliver man som forening, når man sammen med ældrecentrene skaber omsorg og trivsel for de ældre samtidig med at dyrke sin passion. Og det bliver man som ældre, hvis man deltager og måske bidrager til glæden blandt besøgende børn fra en børnehave.}

\section{Hard value \& social value}

Pengeøkonomiens form opfordrer til at spørge: Hvad koster det (hard value)? Hvordan belaster det $\mathrm{fx}$ driftsbudgettet at tilbyde og drive et kombineret yoga- og pilateshold tre gange om ugen før aftensmaden? Den opfordrer også til at spørge: Hvad koster social value? Hvordan belaster det driftsbudgettet endnu mere at lave fælles arrangementer?

Groft sagt adskilles de to værdier - hard value og social value - i mindst to udgiftsposter, som var det adskilte aktiviteter. Og derfra kan udgifter, hyppighed og afmålte antal timer prioriteres, effektiviseres og evalueres - af hvert ældrecenter med hvert sit budget.

Med gaveøkonomien forholder det sig anderledes. Ud af den vokser der en dobbelt bundlinje. Den består for det første i plussum (og eventuelle multipliceringseffekter), der producerer velfærd i form af hard value. Og den består for det andet i værdifællesskaber, der er en oplevelses- og livsværdi, og som sådan udgør en 'social value'. Det er en dobbelt værdi i én og samme gaveøkonomiske operation. Det så vi i Randers, da hver bundlinje ikke krævede hver sin uafhængige indsats fordelt på hvert sit driftsbudget blandt centrene eller blandt foreningerne. Den dobbelte værdi kan opsummeres meget kort:

$$
\text { Gaveøkonomi = plussum (hard value) + livskvalitet (social value). }
$$


Samlet set viser den sammenlignende analyse - styret af form-medie-begrebet samt hard og social value - den principielle velfærdsværdi indeholdt i gaveøkonomien. Der findes et økonomisk alternativ til pengeøkonomien i form af gaveøkonomi, og tilmed er gaveøkonomien en økonomi, hvis velfærdsværdi teoretisk og principielt overgår pengeøkonomiens. Nedenstående tabel formidler et overblik over de to økonomier:

\begin{tabular}{|l|l|l|}
\hline & Pengeøkonomi & Gaveøkonomi \\
\hline Medie & Penge & Gave \\
\hline Form & Transaktion & Gensidighed \\
\hline Program ('hard value') & Nulsum & Plussum \\
\hline Program ('social value') & Egeninteresse & Gensidig forpligtelse \\
\hline Hard value \& social value & Adskilte bundlinjer & Dobbelt bundlinje \\
\hline
\end{tabular}

Tabel 1: Overblik over de to økonomier 1

\section{Del 3: Eksemplariske cases og deres velfærdsværdi}

Ét er den teoretisk-principielle værdi. Noget andet er, hvorvidt og hvordan værdien kommer til syne i praksis. Eller sagt på en anden måde: Der er ingen værdi i at tale om værdi, hvis den ikke praktisk manifesterer sig - både nu og som en tro på fremtiden. Og Randers kan ikke stå alene som eksemplarisk case. Derfor gennemgås tre andre cases, og til sidst sammenfattes de i alt fire cases hen over en fysisk-digital akse samt en større-mindre-akse.

\section{Samsø Energiakademi}

Et af de steder, der har skabt uhørt velfærdsværdi med gaveøkonomisk organisering, er Samsø. Og grunden er den samme: Fordi det kan betale sig, sætter man også pris på den anden. Som den første $\varnothing$ i verden er Samsø 100 pct. selvforsynende med alternativ energi. Ude i verden bliver Samsø derfor også omtalt som et grønt mirakel.

Indledningsvist forsøgte man at igangsætte omstillingen ud fra den pengeøkonomiske adskillelsesmaskine - først en drivende teknisk forvaltning, dernæst tekniske og økonomiske beregninger af hver opgave, og til sidst lokalplanerne i høring. Projektet blev en dundrende fiasko, da de færreste lokale interessenter kunne se værdien i at være med.

Senere gik man anderledes til værks og etablerede Energiakademiet, der skulle fungere som netværkscenter. Eller, i teoretisk forstand, en gaveøkonomisk platform. Bønder, håndværkere, institutioner, færgeselskab og vidensinstitutioner blev koblet sammen i nyskabende samarbejdsprojekter om sol, vind, varme og biogas, fordi det kunne betale sig for hver enkelt gavegiver. I Energiakademiet kaldes det for community power. 
Som illustrationen viser, finder Samsøs grønne gaveøkonomi (cirkler) sted flere steder og på flere niveauer.

Blandt nye initiativer er det planen at opføre et biogasanlæg, der omdanner organisk affald, for eksempel halm fra markerne og husholdningsaffald, til byvarme og biogas til Samsøfærgen.

Den lille gavestrøm består i, at organisk affald tilføres biogasanlægget (gave), mens restaffaldet tilbageføres og gøder markerne (gengave). Denne gavestrøm producerer grøn energi og sparer penge for landmændene på øen. Den store gavestrøm består i, at det, som naturen giver (gave), føres tilbage til naturen som rene ressourcer (gengave). Disse gavecirkler giver god samvittighed, god ressourceøkonomi og grønne tal på bundlinjen.

I dag kan Samsø registrere:

- At ca. 5.000 forskere, virksomheder, politikere, journalister, studerende osv. hvert år besøger øen.

- At Energiakademiets måde at organisere den grønne omstilling på er blevet et benchmark for nationer som Tyskland, Japan og Holland.

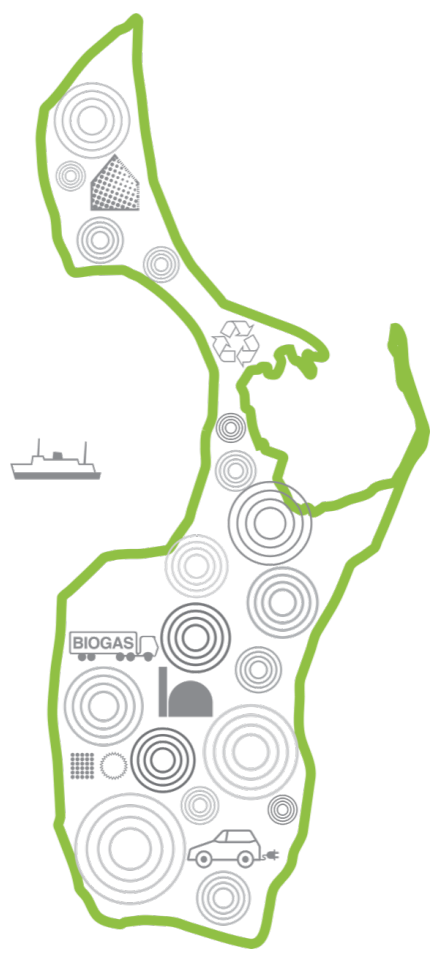

- At øen i dag har befolkningstilvækst.

Opgjort i hard value overgår Samsøs dokumenterede reduktion af $\mathrm{CO}_{2}$ andre lignende initiativer verden over. Opgjort i social value har omstillingen for Samsøs vedkommende ikke været one-off events, men er stadig en løbende og ambitiøs deltagerproces, der betyder, at de fleste på øen færdes vel.

\section{Pol-IT}

Københavns Stadsarkiv stod over for sit livs udfordring i begyndelsen af 00'erne. 1,2 mio. registerkort skulle digitaliseres.

Ud fra gaveøkonomiske principper lykkedes det Stadsarkivet at mobilisere arkivets brugere private og professionelle slægtsforskere, foreninger og forskningsinstitutioner - til at digitalisere registerkortene. Projektet hed Pol-IT. Brugerne indså hurtigt, at jo mere de indtastede (en gave til fællesskabet), desto flere kort kunne de selv tilgå i den fælles database, der blev opbygget af Stadsarkivet (gengaven fra fællesskabet). Projektet blev en kæmpe succes, fordi værdien var forrygende for alle parter:

- Digitaliseringen af registerkort blev løst på syv år. Skulle arkivets medarbejdere selv have stået for digitaliseringen ved siden af deres øvrige opgaver, ville opgaven have taget 100 år.

- Udgiften var beregnet til ca. 50 mio. kr. Opgaven blev løst med et internt årsværk over de syv år.

- Antallet af arkivbrugere blev forøget 50 gange. Det skyldes den digitale adgang til arkivalierne.

Men én ting er at få mere ud af det, som organisationen har i forvejen. Den virkelige værdiforøgelse skal måles på nytteværdien. Digitaliseringen af registerkortene har øget deres anvendelighed i social-historisk og demografisk forskning. Men endnu mere afgørende er betydningen for forskere 
fra sundhedssektoren. De har med arkivets digitalisering langt bedre mulighed for at kortlægge mønstre og årsager til arvelige og epidemiske sygdomme som COVID-19 - og dermed for at udvikle ny viden om sundhedsfremmende og sygdomsreducerende tiltag.

Tallene taler for sig selv, og fordi det er Stadsarkivet, der har gennemført initiativerne, så er værdien, opgjort i hard value, gennemdokumenteret. Hvad angår social value, har især Stadsarkivet oprettet fysiske arrangementer og digitale communities, hvor de forskellige interesser kan mødes og udveksle viden. Alene fordi mange deltagere stortrives i disse fællesskaber.

\section{Tradano}

Tradano er et digitalt loppemarked. Da produktionschef (CPO) og medstifter Martin Suhr hørte, at en hjemløs døde af kulde i København, blev idéen født. Holdet bag Tradono gik i gang med at stable en gaveøkonomi på benene, hvis velfærdsværdi bestod i at hjælpe de mange hjemløse i København gennem vinteren. Det skulle ske gennem donationer af tøj. Gaveøkonomien indbefattede tre gavegivere. Tradano stillede sin digitale platform til rådighed, hvor folk, der gerne ville donere tøj, kunne registrere sig (gave) ${ }^{4}$. Samkørselstjenesten GoMore bidrog med biler og med udbringningen af tøj til herbergerne (gave). Og Københavns Kommune bidrog med viden og formidling af kontaktinformation om de offentligt støttede væresteder i København (gave). Gaveøkonomien var nu skudt i gang, og parterne havde skabt adgang til hinanden. Om aftenen den 25. februar 2016 nåede GoMore rundt til over 80 hjemløse i københavnsområdet. I vinteren 2016 var der derfor ikke mange, der frøs. Gengaven for de tre parter bestod i den værdi, de høstede gennem engagementet:

- Københavns Kommune kunne med en minimal indsats levere en akut indsats over for de hjemløse. Hvis kommunen selv skulle finansiere ikke blot indkøb af varmt tøj til ca. 80 hjemløse, men også udbringning med lønninger til mandskab og evt. leje af biler, ville udgiften i drifts budgetterne vokse betragteligt. Formentlig så betragteligt, at det ikke blev gjort, og at de deraf ville fryse forfærdeligt i vinterkulden.

- GoMore bidrog i den ånd, den er stiftet, nemlig som samkørsel, og fik boostet sit image ganske betragteligt som samkørselstjeneste.

- Tradono forøgede antallet af medlemmer på egen platform, når folk registrerede sig.

Alle parter blev med andre ord 'rig ved at gi', fordi de indgik i en digital gaveøkonomi. Projektet blev så stor en succes, at dette triumvirat gentog indsatsen flere år frem, ikke mindst fordi der også er værdi i at dele en god dag sammen. Derfor blev GoMore og Tradano også enige om at skalere projektet i samarbejde med andre kommuner i landet. Nu er initiativet landsdækkende 5 .

Hvis vi vender tilbage til velfærdsværdien opgjort som hard value og social value, så er Tradano et mindre initiativ målt op imod Energiakademiet på Sams og Stadsarkivet i Københavns Kommune. Derfor er hard value og social value også mindre, men ikke relativt til indsatsen. Det er ift. hard value initiativer, der med få midler og en mindre organisationsindsats har betydet, at de hjemløse kunne færdes vel i kulden. Ift. social value var medvirken i Tradanos initiativ en skelsættende begivenhed for de medvirkende. 


\section{Variation og bredde}

Alle de nævnte cases er listet i nedenstående graf, der også tæller projekt 'lån et lokale' blandt ældrecentrene i Randers Kommune.

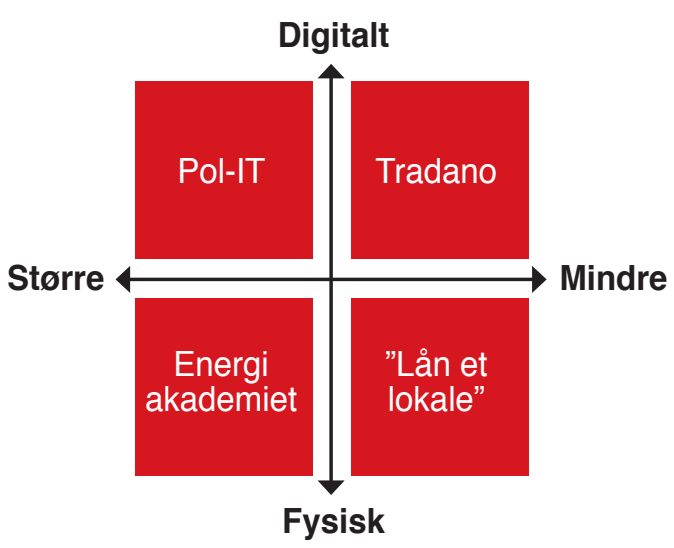

Fig. 1: Gaveøkonomi variation og bredde 1

De fire illustrative cases' placering i grafen viser spændvidden af gaveøkonomier i variation og bredde. Variationen i form af digitale eller fysiske (den lodrette akse) og bredden i form af størrelser (den vandrette akse).

Grafen er bevægelig og langtfra definitiv, hvilket understreger to forhold. For det første, at gaveøkonomier ofte bevæger sig fra små til store projekter, al den stund at de har succes og i denne proces også kan bevæge sig mod at blive mere digitale. Gaveøkonomien i 'Lån et lokale' blandt ældrecentrene i Randers startede fx gennem nogle få kontakter, men voksede sig større og blev dermed en tand mere digitale. For det andet, at de fleste fysiske gaveøkonomier i et vist omfang også er digitale, og at digitale gaveøkonomier ikke udelukker fysisk tilstedeværelse. Gaveøkonomien i Tradano var fx kun lykkedes gennem en kombination af fysiske møder mellem de tre parter og fysisk udbringning, selvom organiseringen skete på Tradanos digitale platform.

\section{Konklusion}

Artiklen har bidraget med et teoretisk-illustrativt bud på, hvordan gaveøkonomier kan bidrage væsentligt til vores velfærdsværdi i betydningen at 'færdes vel'.

Det første hovedbudskab består i, at pengeøkonomiens rationale ikke er det eneste rationale, der fører til, at vi færdes vel, og ej heller den eneste vej ud af det økonomiske efterslæb, som COVID-19 har skabt. Der findes et alternativ til den pengeøkonomiske velfærdsautomatisme, som består i gaveøkonomien og dermed en anden vej ud af det økonomiske efterslæb.

Det andet hovedbudskab består i, at gaveøkonomien, til forskel fra pengeøkonomien, producerer velfærdsværdi gennem relationer og ikke adskillelse, og at værdien overgår pengeøkonomiens. At den overgår pengeøkonomiens, er en teoretisk og principiel konklusion, men blev illustreret gennem fire eksemplariske cases fordelt hen over to akser - fysisk-digital og større-mindre. Pointen 
er, at gaveøkonomien også udgør en praktisk organisering af vores vel-færden, og at vi allerede kan konstatere målbar og dokumenteret velfærdsværdi opgjort i hard value og social value.

Gaveøkonomiens potentiale er et potentiale, der skal ses i lyset af den underskov af nye organiseringer og værdifællesskaber, der vokser frem, og som går under betegnelser som deleøkonomi, kollaborativ økonomi, cirkulær økonomi og til dels samskabelse. Hvad der kendetegner dem alle, er, at de skaber værdi gennem relationer, og specielt de relationer, der bygger på ressourceudvekslinger i form af gavegivning.

Men hvad bliver udfordringen så? Spørgsmålet skal ses i lyset af, at pengeøkonomien er den overvejende økonomi, hvormed vores moderne velfærdsstat igennem de sidste 25 år er opbygget.

Udfordringen består i, at:

- Vi skal bekæmpe blindhed. Det indebærer, at vi fortæller os selv, at det modsatte af penge økonomi ikke er 'ikke-økonomi', men anden økonomi.

- Vi skal bekæmpe 'dominans'. Det indebærer, at vi fortæller os selv, at den pengeøkonomiske overdeterminering ikke alene er vejen ud af efterslæbet, men at vi er opmærksomme på den velfærdsværdi, som andre økonomier, deriblandt gaveøkonomien, tilbyder.

Vi skal, i en lettere omskrivning af et gammelt ordsprog, ride på to (økonomiske) heste. Og heri består udfordringen, hvis vi skal komme om på den anden side af coronakrisen med velfærden i behold.

Det indebærer en politisk udfordring, al den stund at gaveøkonomiens velfærdsværdi bør anerkendes og stimuleres - af Finansministeriet og det stigende antal økonomiske rådgivere i Statsministeriet og andre ministerier.

Det indebærer en ledelsesudfordring, for det er her, de konkrete initiativer skal udspringe og de konkrete erfaringer drages. Megen ledelse handler om adskillelse, om at svinge ragekniven, der adskiller funktioner, ansvar og opgaver samt opdeler velfærden i ydelser og enhedsomkostninger. At opbygge, vedligeholde og videreudvikle gaveøkonomiske organiseringer indebærer modet til at erstattes flere af disse adskillelser med gaveøkonomiske relationer.

Det indebærer slutteligt en forskningsudfordring, for det er her, den fremsatte tese om øget velfærd og værdi ultimativt kan be- eller afkræftes. Det vil desuden indebære, at gaveøkonomiens voldsomme potentiale teoretisk udvikles, empirisk undersøges, og endda udsættes for berettiget kritik og evaluering. Og i takt hermed er det også en undervisningsopgave, bl.a. fordi efteruddannelsessektoren er et outlet for forskningen og en brobygning til praksis og offentlige ledere, der kan sætte gaveøkonomien i lokal kontekst og starte egne initiativer - ligesom de gjorde i Randers. 


\section{Litteratur}

Acemoglu, D., Laibson, D. \& List. J. (2019). Economics, Pearson.

Andersen, N. Å. (2003). Discursive Analytical Strategies: Understanding Foucault, Koselleck, Laclau, Luhmann. Policy Press. https://doi.org/10.2307/j.ctt1t898nd

Andersen, N. Å. (2019). Form og medie: Intermedialitet og analysestrategi på tværs af perceptionsmedier, kommunikationsmedier, biomedier og fysiske medier. Nyt fra Samfundsvidenskaberne. https://doi.org/10.7146/aul.177.137

Bierman, H. S., \& Fernandez, L. F. (1998). Game theory with economic applications. Pearson College Division.

Boldyrev, I. A. (2013). Economy as a Social System: Niklas Luhmann's Contribution and its Significance for Economics. American Journal of Economics and Sociology, 72(2), 265-292. https://doi.org/10.1111/ajes.12013

Bourdieu, P (1979). Symbolic power. Critique of Anthropology, 4(13-14), 77-85. https://doi.org/10.1177/0308275X7900401307

Bourdieu, P (1996). The work of time. I: Komter AE (Red.) The Gift: An Interdisciplinary Perspective (s. 135-147). Amsterdam: Amsterdam University Press.

Eisenstein, C. (2011). Sacred Economics: Money, Gift, and Society in the Age of Transition. Berkeley, CA: North Atlantic Books.

Ejersbo, N., \& Greve, C. (2014). Moderniseringen af den offentlige sektor. Akademisk Forlag.

Fremtidens velfærd - vores valg (2005). https://www.yumpu.com/da/document/view/18267090/ fremtidens-velfaerd-vores-valg-finansministeriet

Fukuyama, F. (1995). Trust: The Social Virtues and the Creation of Prosperity (No. D10 301 c. 1/c. 2). New York: Free Press Paperbacks.

Gabbay, S. M., \& Leenders, R. T. A. (Eds.). (2001). Social capital of organizations. Emerald Group Publishing Limited.

Gibbons, R. S. (1992). Game theory for applied economists. Princeton University Press.

Graeber, D. (2013). It is value that brings universes into being. HAU: Journal of Ethnographic Theory, (2), 219-243. https://doi.org/10.14318/hau3.2.012

Hasle, P., Thoft, E., \& Olesen, K. G. (2010). Ledelse med social kapital.

Hermansen, S., \& Nørretranders, T. (2013). Fælledskab = fælled + fællesskab. Samsø Energiakademi, Samsø.

Jie, M. (2011). The Plus-sum Relations between Capital and Labor in the Creation of Value: A New Marxian Explanation Based on the Proportional Theory of Value Creation [J]. Economic Research Journal, 4(3).

Kielburger, C., Branson, H., \& Kielburger, M. (2018). WEconomy: You Can Find Meaning, Make A Living, and Change the World. John Wiley \& Sons. 
Knudsen, M. (2014). Metodisk overrasket: Om systemteori og funktionel metode (s. 19-40). Nyt fra Samfundsvidenskaberne.

Kumar, M. S. (2011). Are joint ventures positive sum games? The relative effects of cooperative and noncooperative behavior. Strategic Management Journal, 32(1), 32-54.

https://doi.org/10.1002/smj.867

Luhmann, N. (1982). 9. The Economy as a Social System, $i$ The differentiation of society (pp. 190-226). Columbia University Press.

Luhmann, N. (1995). Social systems. Stanford University Press.

Luhmann, N. (2016). Samfundets samfund. Hans Reitzel.

Mas-Colell, A., Whinston, M. D., \& Green, J. R. (1995). Microeconomic theory (Vol. 1). New York: Oxford University Press.

Mauss, M. (2002). The gift: The form and reason for exchange in archaic societies. Routledge. Mauss, M. (1925). The gift. Cohen \& West, London.

Moltke, H.V. \& Graff, H. (2014). Social Kapital i Organisationer. Dansk Psykologisk Forlag. Jørgensen, J. K. (18/3/2021). KL-formand: Coronaefterslæb kræver løft i økonomien. Nyhedsmagasinet Danske Kommuner. http://www.danskekommuner.dk/Nyhedsarkiv/2021/ Marts/18/KL-formand-Coronaefterslab-kraver-loft-i-okonomien-i-2022/

Nørretranders, T. (2003). Det generøse menneske. ArtPeople.

Olesen, K. G., Thoft, E., Hasle, P., \& Kristensen, T. S. (2008). Virksomhedens sociale kapital: Hvidbog. Det Nationale Forskningscenter for Arbejdsmiljø (NFA).

Pedersen, O. K. (2011). Konkurrencestaten. Hans Reitzels Forlag.

Pedersen, D. (2004). Offentlig ledelse i managementstaten. København, Samfundslitteratur.

Putnam, R. D. (1995). Tuning in, tuning out: The strange disappearance of social capital in America. Political Science and Politics 28(4). 664-683. https://doi.org/10.1017/s1049096500058856

Putnam, R. D. (2000). Bowling alone: America's declining social capital. I: L. Crothers \& C. Lockhart (red.), Culture and Politics (s. 223-234). New York: Palgrave Macmillan.

https://doi.org/10.1007/978-1-349-62397-6_12

Putnam, R. D. (red.) (2004). Democracies in Flux: The Evolution of Social Capital in Contemporary Society. New York: Oxford University Press.

Randers Kommune. (3/7/2017). Der kom mere liv på ældrecentrene. Randers Kommune. ${ }^{1}$ https://www.randers.dk/nyhedsarkiv/der-kom-mere-liv-paa-aeldrecentrene/

Sørensen, E., \& Torfing, J. (2018). Den offentlige sektor som en arena for samskabelse. I: M.K. Fogsgaard \& M. de Jongh (red.), Ledelse og samskabelse i den offentlige sektor, (s. 30-61). Dansk Psykologisk Forlag. https://doi.org/10.7146/politica.v26i3.67855

Thygesen, N. (2007). Steering technologies as observation. Cybernetics \& Human Knowing, 14(2-3), 151-172. 
Thygesen, N. (2019). The gift economy and the development of sustainability. Local Economy, 34(6), 493-509. https://doi.org/10.1177/0269094219882261

Thygesen, N. (2020). Gaveøkonomi - en vej til ny velfærdsværdi. Samfundslederskab i Skandinavien, 36(1), 26-51. https://doi.org/10.22439/sis.v36i1.6165

Thygesen, N. \& Löfvall, S. (2020). Gaveøkonomi - ny vej til bedre velfærd. Gyldendal Public. 